\title{
XI Conference of the Polish Association for the Study of the Liver
}

\author{
6-7 November 2020 \\ Bydgoszcz/On-line
}

Abstracts

The abstracts are printed in the form sent by authors, accepted by the Scientific Programme Committee 


\section{Unexpected cause of abdominal distension}

Katarzyna Szczepaniec' ${ }^{1}$ Joanna Musialik², Anna Kwaśniewska³ Klaudia Adamczewska', Paulina Klarczyńska', Andrzej Więcek²

'Faculty of Medical Science, Medical University of Silesia in Katowice, Poland

2Department of Nephrology, Transplantation and Internal Medicine, Faculty of Medical Science, Medical University of Silesia in Katowice, Poland

${ }^{3}$ Division of Radiology, Mielecki University Hospital, Medical University of Silesia in Katowice, Poland

Case presentation: Fifty-five-years-old male, previously suffered only from hypertension, was diagnosed because of significant abdominal distension. The problem has begun a few years earlier but the patient was convinced that it was only abdominal obesity. The reason of starting the diagnostics was the appearance of non-characteristic abdominal pain. In physical examination: abdominal circumference $126 \mathrm{~cm}$, abdomen arched above the level of the chest, tightens abdominal skin with an uneven surface, locally modeling on palpable, spherical structures located in the abdomen cavity.

In an ultrasound examination, the multiple fluid cavities in abdomen cavity with no possibility of imaging the other organs have shown. In computer tomography scans, a significantly enlarged liver of $33 \mathrm{~cm}$, with the presence of numerous cysts (the largest $12 \mathrm{~cm}$ in diameter) have found which allowed to diagnose polycystic liver disease (PLD).

Despite the normal liver and kidney function and because of abdominal pain due to hepatomegaly and deterioration of quality of life, the patient was qualified for liver transplantation.

Discussion: PLD is very rare genetic disease and symptomatic PLD occurs mainly in the context of isolated polycystic liver disease (PCLD) and autosomal dominant polycystic kidney disease (ADPKD) with extra-kidney manifestation. Screening mutations of the genes causing PCLD (PRKCSH and SEC63) or ADPKD (PKD1 and PKD2) confirm the clinical diagnosis 1 . In PCLD more than 20 fluid-fulfilled hepatic cysts are found. In ADPKD, renal failure due to polycystic kidneys and non-renal extra-hepatic features are common in contrast to PCLD. Usually asymptomatic, but one of the five patients may feel abdominal pain, distension or nausea. Uncommonly, surgery, including transplantation is needed ( $0.003 \%$ of all indications).
Conclusions: Abdominal distension may be a symptom of a various diseases. The most common cause are ascites or neoplasm, but in differential diagnosis, rare causes such as PLD should be taken into consideration.

\section{Liver transplantation - successive therapy of liver and respiratory insufficiency}

\author{
Paulina Klarczyńska', Joanna Musialik², \\ Anna Kwaśniewska', Klaudia Adamczewska', \\ Katarzyna Szczepaniec ${ }^{1}$, Robert Król' ${ }^{4}$ Andrzej Więcek ${ }^{2}$ \\ 'Faculty of Medical Science, Medical University of Silesia in Katowice, \\ Poland \\ 2Department of Nephrology, Transplantation and Internal Medicine, \\ Faculty of Medical Science, Medical University of Silesia in Katowice, \\ Poland \\ ${ }^{3}$ Division of Radiology, Mielecki University Hospital, Medical \\ University of Silesia in Katowice, Poland \\ ${ }^{4}$ Department of General, Vascular and Transplant Surgery, Faculty \\ of Medical Science, Medical University of Silesia in Katowice, Poland
}

Case presentation: Fifty-eight-years-old female, was diagnosed because of severe resting dyspnoea increasing for 5 months. In physical examination: central cyanosis, digital clubbing and platypnea as well as jaundice, peripheral oedema and ascites were found. In arterial blood gasometry, the hypoxaemia (oxygen pressure $-71 \mathrm{mmHg}$ ) and orthodeoxia - decrease in arterial blood saturation by $4 \%$ in standing position compared to the lying position were examined. In further diagnostics with contrast echocardiography, the intrapulmonary leakage was shown and dilated pulmonary vessels in the lower lobes in high resolution computed tomography (HRCT) of the chest were found. At the same time, the diagnostics of liver failure was carried out. Positive anti-HCV antibodies and HCV viremia of $29955 \mathrm{IU} / \mathrm{ml}$ (HCV genotype 1b), were found. Finally, decompensated liver cirrhosis due to hepatitis $\mathrm{C}$ virus infection and hepatopulmonary syndrome (HPS) were diagnosed. The patient was referred to antiviral therapy and after successful treatment she was classified to liver transplantation (LTx). During the waiting period the progress of HPS was observed and the patient had to use a home oxygen concentrator. Three months after LTx, the symptoms of HPS have disappeared completely.

Discussion: HPS is a complication of hepatic diseases and/or portal hypertension connected with circulatory oxygenation disorder due to intrapulmonary 
leakage resulting from pulmonary vascular dilatation. HPS accompanies chronic liver disease with varying frequency, occurring in $15-20 \%$ of patients with cirrhosis. The main symptom of HPS is platypnea-orthodeoxia syndrome, it should be differentiate from intracardiac leakage in the course of heart defects.

Conclusions: HPS is an independent indication for LTx, which is the only effective method of HPS therapy, whose symptoms disappear in more than $85 \%$ of patients within 6-12 months after LTx. In patients with chronic liver diseases, in case of chronic dyspnoea, HPS should be taken into consideration.

\section{From epigastric pain to liver transplantation}

\author{
Klaudia Adamczewska', Joanna Musialik², \\ Anna Kwaśniewska ${ }^{3}$, Katarzyna Szczepaniec ${ }^{1}$, \\ Paulina Klarczyńska', Robert Król'4, Andrzej Więcek² \\ ${ }^{1}$ Faculty of Medical Science, Medical University of Silesia in Katowice, \\ Poland \\ 2Department of Nephrology, Transplantation and Internal Medicine, \\ Faculty of Medical Science, Medical University of Silesia in Katowice, \\ Poland \\ ${ }^{3}$ Division of Radiology, Mielecki University Hospital, Medical \\ University of Silesia in Katowice, Poland \\ ${ }^{4}$ Department of General, Vascular and Transplant Surgery, Faculty \\ of Medical Science, Medical University of Silesia in Katowice, Poland
}

Case presentation: Thirty-six-year-old female, previously healthy, was diagnosed because of non-specific abdominal pain of moderate severity, localized in the right epigastric region. In physical examination, she was felt only slight discomfort in the right epigastrium. After several days the symptoms persistent, abdominal ultrasound (US) was performed and an enlarged liver with numerous hypoechoic focal lesions having a hyperechoic rim were shown. Further diagnostics with magnetic resonance imaging revealed described changes with the largest dimension up to $45 \mathrm{~mm}$ and a characteristic image of the shooting target. Pathomorphological examination of coarse needle biopsy specimen confirmed the initial diagnosis of hepatic epithelioid hemangioendothelioma (HEHE) (CD31(+), CD34(+), Ki67 positive in individual cells). No extrahepatic changes were found and after quick qualification, the patient successfully underwent liver transplantation.

Discussion: Diagnostics of abdominal pain is a process that often requires sequencing of many lab- oratory and imaging tests. Predominantly, detected focal liver lesions are not associated with reported complaints, in most cases they have a benign nature, e.g. cysts or hemangiomas. However, in a certain percentage of cases, focal lesions are classified as malignant and are indication for surgical resection or even liver transplantation. HEHE is a very rare, endothelial malignant liver tumor $(<1$ case per million) with uncertain biological behavior which usually falls between benign hemangioma and malignant angiosarcoma. An extrahepatic locations most commonly include lungs and bones. The course of the disease is asymptomatic for a long time, and in multifocal cases the only solution is liver transplantation. Survival and survival rates without recurrence after 5 and 10 years after transplantation are $83 \%$ and $74 \%$ as well as $82 \%$ and $64 \%$, respectively.

Conclusions: The history of this patient confirms the necessity for detailed diagnostics of every abdominal pain.

\section{Is chronic hepatitis E virus infection problem in HIV-infected population?}

\author{
Dorota Dybowska', Dorota Kozielewicz ${ }^{1}$, \\ Aleksandra Szwed-Kowalska² \\ 'Department of Infectious Diseases and Hepatology, Faculty \\ of Medicine, Nicolaus Copernicus University in Toruń, Poland \\ ${ }^{2}$ Provincial Hospital of Observation and Infectious Diseases \\ in Bydgoszcz, Poland
}

Introduction: Hepatitis E in Europe is mostly subclinical or acute and self-limiting course. However, persistent hepatitis $\mathrm{E}$ virus (HEV) infection is describe among immunocompromised individuals. This problem has not been well established in the HIV-infected population. Chronic HEV infection among patients with HIV infection has mostly been described in those with CD4+ T-cell count $<200 / \mathrm{mm}^{3}$.

Aim of the study: To determine whether hepatitis E takes chronic courses in HIV-infected patients treated in our hospital.

Material and methods: $36 \mathrm{HIV}$ patients ( 6 female, 30 male, age 21-62 years, mean age 43.8 ) were divided in two groups. To the first group (I) belong $21 \mathrm{pa}-$ tients with CD4+ T-cell count $<200 / \mathrm{mm}^{3}$ and to the second (II) 15 with CD4+ T-cell count $>200 / \mathrm{mm}^{3}$. All cases were tested for both HEV antibodies and HEV RNA. Anti-HEV IgM was detected by the VIDAS Anti - HEV IgM (HEVM) Biomerieux, anti-HEV IgG by VIDAS Anti-HEV IgG (HEVG) Biomerieux assay. 
Viremia HEV was detected in two step manner: QIAamp DSP Virus Kit, QIAGEN was used for isolation and ampliCube HEV 2.0, MIKROGEN DIAGNOSTIK for amplification.

Results: Anti-HEV IgM was not detected in any cases. Anti-HEV IgG was detected in $4 / 21$ patients from group I and 8/15 from group II. None of the patients tested had HEV RNA positive. There was one cirrhotic patient anti-HEV IgG positive in each group. Both of them had coinfection $\mathrm{HCV} / \mathrm{HBV}$.

Conclusions: About one third of HIV-infected patients show serological evidence of previous $\mathrm{HEV}$ contact. No evidence of persistent HEV infection was detected.

\section{Evaluation of liver fibrosis in patients with Wilson's disease}

Adam Przybyłkowski', Jowita Szeligowska', Magdalena Januszewicz², Joanna Raszeja-Wyszomirska³, Benedykt Szczepankiewicz ${ }^{4}$, Piotr Nehring', Barbara Górnicka ${ }^{4}$, Tomasz Litwin ${ }^{5}$, Anna Członkowska ${ }^{5}$

\section{'Klinika Gastroenterologii i Chorób Wewnętrznych, Warszawski Uniwersytet Medyczny, Polska \\ 2II Zakład Radiologii Klinicznej, Warszawski Uniwersytet Medyczny, Polska \\ ${ }^{3}$ Klinika Hepatologii i Chorób Wewnętrznych, Warszawski Uniwersytet Medyczny, Polska \\ ${ }^{4}$ Katedra i Zakład Patomorfologii, Warszawski Uniwersytet Medyczny, Polska \\ 5II Klinika Neurologiczna, Instytut Psychiatrii i Neurologii w Warszawie, Polska}

Aim of the study: Staging of fibrosis in chronic liver disease is important for prognosis and treatment planning. Liver biopsy is the gold standard in fibrosis assessment; however, new methods for fibrosis and stiffness measurement exist that have not been evaluated in patients with Wilson's disease (WD). To evaluate the accuracy of collagen proportionate area (CPA), transient elastography (TE) and shear wave elastography (SWE) in the assessment of liver fibrosis in adult patients with WD.

Material and methods: In this retrospective study of 60 patients with WD, results of percutaneous liver biopsy results including Ishak score and CPA were compared with liver stiffness measured with TE and SWE.

Results: The youngest patient was 18 years old and the oldest was 62 years old, with a mean age of 40 years, distribution of sexes was equal. All patients were treat- ed with zinc salts or D-penicillamine for at least one year. Macrovacuolar steatosis was detected in 35 (58\%) patients. Forty-eight patients $(80 \%)$ had an Ishak score of 3 or less based on liver biopsy, and cirrhosis (Ishak score 5 to 6$)$ was diagnosed in 5 patients (8\%). CPA correlated with Ishak score $(r=0.45, p=0.001)$ and TE results correlated with SWE measurements $(r=0.80$, $p=0.0001)$. In contrast, TE or SWE did not significantly correlate with Ishak score or CPA. When liver stiffness measurements were plotted against measured Ishak scores, it appeared that TE and SWE increased in the early stages of disease up to Ishak score of 2 or 3 and then decreased in the advanced stages. There was no significant correlation between measurements of CPA, TE or SWE and any of the clinical features and laboratory prognostic scores tested (De Ritis ratio, FIB-4, APRI, Bonacini and MELD).

Conclusions: Collagen content assessment may be useful for estimation of liver fibrosis in patients with WD. time-point elastographic liver stiffness measurement has limited diagnostic value in WD.

\section{Klinika i leczenie raka wątrobowokomórkowego na terenie północno-wschodniej Polski}

\author{
Aleksandr Tarasik', Marcin Januszkiewicz², \\ Tadeusz W. Łapiński ${ }^{3}$, Robert Flisiak ${ }^{3}$ \\ 'Oddział Chirurgii Onkologicznej z Pododdziałem Chirurgii Piersi \\ i Rekonstrukcji, Białostockie Centrum Onkologii, Polska \\ 20ddział Chirurgii Ogólnej, Małoinwazyjnej i Onkologicznej, \\ Szpital Wojewódzki w Białymstoku, Polska \\ ${ }^{3}$ Klinika Chorób Zakaźnych i Hepatologii, Uniwersytet Medyczny \\ w Białymstoku, Polska
}

Wstęp: Rak wątrobowokomórkowy (hepatocellular carcinoma - HCC) jest guzem niejednorodnym charakteryzującym się złożonym procesem rozwoju. Jego powstawanie związane jest $\mathrm{z}$ uwarunkowaniami genetycznymi regulowanymi przez aktywację lub supresję onkogenów komórkowych.

Cel pracy: Wśród chorych na HCC oceniono występowanie marskości wątroby, zakażenia HBV lub $\mathrm{HCV}$, nadużywania alkoholu oraz stłuszczenia wątroby. Określono przydatność AFP w diagnostyce HCC. Określono skuteczność terapii stosowanych w leczeniu HCC.

Wyniki: Badaniami objęto 104 chorych $\mathrm{z}$ rozpoznanym HCC. Ponad 90\% chorych z HCC było w wieku powyżej 45 lat. Nowotwór występował częściej u mężczyzn w porównaniu z kobietami. Marskość 
wątroby rozpoznano u $72 \%$ chorych, nadużywanie alkoholu u 35\%, zakażenie HCV u 35\%, zakażenie HBV u $24 \%$, a stłuszczenie wątroby u $13 \%$. Wśród zakażonych HBV u 9 z 24 (36\%) chorych HCC rozwinął się pomimo skutecznej terapii przeciwwirusowej. Najwyższe stężenie AFP stwierdzono u pacjentów zakażonych HBV. Skuteczność resekcji części wątroby pozwoliła na średni czas przeżycia ok. 19 miesięcy, a termoablacji 16 miesięcy.

Wnioski: Głównym czynnikiem predysponującym do rozwoju HCC jest marskość wątroby, a na kolejnym miejscu - nadużywanie alkoholu i zakażenie HCV. Skuteczne leczenie przeciwwirusowe chorych zakażonych HBV nie gwarantuje braku rozwoju HCC. Wykluczenie z leczenia 29\% pacjentów z HCC z powodu zaawansowanego procesu chorobowego świadczy o niedostatecznie rozwiniętej profilaktyce tego nowotworu. Wydaje się, że resekcja części wątroby (anatomiczna i nieanatomiczna), jak również termoablacja (przezskórna i śródoperacyjna) są podobnie skutecznymi metodami w terapii HCC.

\section{What is the benefit of abdomen advanced ultrasound simulation?}

Rafał Krygier, Alfred Rajczyk, Romana Łukaszewska-Olszewska

NZOZ Gemini, Żychlin

Simulator training improves ultrasound scanning performance on patients. Use reproducible training content, as real ultrasound patient data, which are documented and marked with regions of interest. The impact of a simulator system is the number of available lesson hours. A virtual model does not challenge a long time as real cases do not miss details, causes and relationships. The Schallware Simulator is based on clinical ultrasound data offering pathological findings as well as variants of anatomical textures and structures in over 500 real patients (multimorbid). In additiaon, virtual model of abdomen are available for continuous scanning around organs to help beginners better understand the body's anatomy. Moreover allows doctors to practice ultrasound diagnosis congruent with real conditions. Moving the tracked probe over the torso produces an exact B-mode image of the case chosen. In each module, the simulator offers a set of patients. Every one of these is represented by several $3 \mathrm{D}$ volumes, or more precisely six abdominal and two intercostal volumes. To facilitate this data of single patients entire has been acquired, averaging around 6000 images per patient. All documented cases include a medical history, questions leading to a diagnosis, comments on ultrasound diagnosis (i.e. what is visible with the simulator) and a pathological description. The simulator enables you to find physiological or pathological structures using regions of interest (ROI). We can additionally take advantage of the simulator as an ultrasound device using a login mode for studies, measurements, storing of freeze-frame images, creating pdf reports or writing questions and answers for tutorials or examinations in a QnA format. A few years ago at EASL congresses my adventure with simulators began. This "patient" is patient, still breathing in with clearly visible abdominal organs and rarely seen pathologies. Perfect for training and checking skills, including exam. Despite many other ultrasound courses, I recommend this verification of knowledge to everyone. After many efforts, the first ultrasound course on the Schallware simulator took place in Pabianice in February 2020. Ability to perform abdominal ultrasound is the basic work tool of a hepatologist. 